tion and cultivation, vitality of seeds, germination of seeds, and changing seed. The Report of the Botanist consists in an illustrated descriptive list of certain economic plants, and a chapter upon the fungous diseases of plants. Next comes the Report of the Microscopist, dealing with textile fibres, parasites of domestic fowls, crystals of fats-butter, beef, and lard -beautifully illustrated with coloured plates, and highly interesting in connection with the adulteration of butter. I must content myself with a mere enumeration of the Reports of the Chemist, the Chief of Division of Forestry, the Entomologist, the Statistician, the Chief of the Bureau of Animal Industry, a Report on wheat-culture in India, and truck-farming, "or the growing at the South, exclusively for the Northern markets, as a distinct business, of all (or a selection of) such fruit and vegetables as would be likely to arrive at their destination in good condition."

Before concluding this first notice, I must mention the fine manner in which the work is illustrated by tables, diagrams, maps, engravings, and coloured plates. The illustrations of fat-crystals have been already mentioned. Other illustrations are a delicately-tinted and beautifully-drawn collection of twelve edible mushrooms common in the United States; a coloured picture of the transformation of Cicada septemdecim, taking place in every stage, on a leafy branch of oak ; and splendidly-executed coloured plates illustrative of verminous bronchitis and of ulcerated cæcum in the Section of Animal Industries.

To an Englishman, probably the most interesting portion of the book will be the Report of the Statistician, with its tables of exports land imports, area, and productive power of the United States. The control which the States exercise over the wheat trade of the world is indicated by a diagram showing that, as the yicld per acre of the States rises, the prices of wheat all over the world fall; and as the average yield diminishes the prices rise. This correspondence between yield and price is even more precise in the cace of oats and maize than in the case of wheat, because, as the Statistician remarks, "we make our own prices for corn and oats, while Liverpool has much to do with the price of wheat."

A very striking diagram, which cannot fail to be of deep interest to those who feel themselves cramped for room in overcrowded England, is one showing the proportion of forests, farms, and unimproved or waste lands in the United States. The vast and almost appalling extent of the first and last sections shows the inexhaustible resources of the country. In Texas, California, Dakota, Montana, New Mexico, Arizona, Nevada, Colorado, Wyoming, Oregon, Idaho, Utah, Kansas, Minnesota, Nebraska, and even Washington, the amount of cultivated or farmed land is quite insignificant compared with the vast tracts of forest and of unreclaimed land. One cannot but reflect upon the fact that a country so wealthy in the raw material of the soil should yet find it advisable to spend money lavishly upon scien tific investigation of agricultural difficulties, while England, with her restricted area and dense population, should allow her agri. culture to drift, as though its welfare were of no importance, o its downfall no cause of anxiety.

JOHN WRIGHTSON.

\section{WEIGHTS AND MEASURES.}

THE Annual Report of the Standards Department of the Board of Trade on its proceedings and business during the past year has been recently issued. It would appear that the Department has of late been pressingly engaged on ordinary work under the several Acts of Parliament which govern its proceedings, but there are some matters of scientific interest referred to in the Report to which we might invite attention.

Standards of various kinds, for determining capacity, length, weight, and volume, continue to be verified for official purposes, or for private use in aid of scientific research or otherwise, without fee or any charge.

Further representations have been made as to the want of a standard hydrometer, accurately adjusted to the legal units of weight and measure in force in this country, for determining the specific gravities of liquids heavier than alcohol.

The sanction of the Treasury has been obtained to the purchase, at an estimated cost of $£$ Iooo, of copies of the new metric standards of length and weight, which are being prepared at Paris, under the directions of the Comité International des Poids et Mesures.

An exhanstive series of comparisons of the geodetic standards of New South Wales with those of the Board of Trade and the Ordnance Survey has been made by Mr. H. C. Russell, Government Astronomer, Sydney, and Mr. H. J. Chaney, of the Standards Department; of which comparisons a separate Report has been prepared.

In a memorandum on the accurate definition of metrological units, which is attached to the Report, it is pointed out, with regard to metric units, that the relation of the metric unit of weight, the kilogramme, to the metric units of length and capacity is not based on a natural constant, as is generally taught. If the kilogramme prototype were lost, for instance, it would not be restored by reference to the weight of water contained in the cubic-decimetre. The latest experiments have shown that the cubic-decimetre of distilled water $\left(t=4^{\circ} \mathrm{C}\right.$. $)$ weighs, under given conditions, nearly 100 milligrammes less than a true kilogramme weighs. Hence the value of the unit of capacity, the litre, depends on the kilogramme weight, and not on the metre measure. There is de facto, it is stated, no more scientific relation between the metric unit of weight, the kilogramme, and the metric units of length and capacity, the metre and litre, than there is between the present conventional metre and the original natural standard of one ten-millionth part of the Paris meridian.

It is curious to note, session after session, how large an amount of purely technical work continues to be added to the ordinary duties of local officers such as inspectors of weights and measures, inspectors of gas, inspectors of petroleum, \&c. During the past year we notice, for instance, that the Legislature has, amongst other things, made it necessary for all weighing. machines used at mines in determining colliers' wages, as well as machines used in weighing cattle to be examined and tested by the local inspectors, many of whom are simply constabulary officers. Now the testing of a compound lever weighingmachine requires some special knowledge, but many of the officers have, it would appear, no technical qualification whatever for such duty. Hence the duties imposed by the Legislature are in many districts carried out in an indifferent and perfunctory manner; and another practical instance is afforded of the necessity for increased technical education of that class from which the above local officers are drawn. Without requiring, as in Germany, that every such local officer-as an inspector of weighing-machines-should pass a technical examination, it would certainly appear to be desirable before such officer is appointed that the local authorities (as the County Justices and Town Councils) should see that he has had some proper scientific training.

\section{UNIVERSITY AND EDUCATIONAL} INTELLIGENCE.

OXFORD.-The term has been very uneventful so far as the Natural Science School is concerned. There has been no new departure in scientific education, and no important conflict with the rest of the University. The most satisfactory feature of the term is the granting of $£ \mathrm{I} 200$ to be expended during the next three years on the Pitt-Rivers Anthropological Museum. The collection has been enriched by the transference of a quantity of valuable objects from the Ashmolean Museum, and by private gifts; the arrangement and cataloguing of the whole collection is proceeding steadily under the superintendence of $\mathrm{Mr}$. Balfour of Trinity.

Unfortunately Prof. Moseley's continued illness has made it necessary for him to apply for prolonged leave of absence. Dr. S. J. Hickson, Downing College, Cambridge, will act as his deputy next term.

The Millard Laboratory for Experimental Mechanics at Trinity is to be enlarged during the vacation by the addition of a lecture-room and drawing-room, which formed part of Mr. Bosanquet's Laboratory at St. John's.

CAMBRIDGE. - At the annual election of candidates not yet in residence, the following awards were made :-

Foundation Scholarships: H. H. Hough $(£ 80$, in Mathematics), St. Paul's School; A. G. Pickford ( $₫ 60$, in Mathematics and Physics), the Owens College, Manchester; E. F. Gedye ( $£ 50$, in Mathematics), Leys School, Cambridge. Minor Scholarships: F. A. Leete ( $£ 50$, in Mathematics), Wellingborough School ; C. Robertson ( $£ 50$, in Mathematics), Norwich School. Exhibitions: E. W. MacBride $(£ 50$, in Natural Science), Queen's College, Belfast; V. M. Turnbull ( $£ 336 s .8 d$., in Mathematics), St. Bee's School. Sizarships: $\Lambda$. W. Cuff, in Natural Science; R. E. Baker, in Natural Science; W. N. Maw and G. F. J. Rosenberg, in Mathematics. 